DOI: $10.14451 / 2.125 .11$

\title{
ПРАВОВАЯ ПРИРОДА НОТАРИАТА В РОССИЙСКОЙ ФЕДЕРАЦИИ
}

\author{
(c) 2018 Лошкарев Андрей Викторович
}

кандидат юридических наук, доцент, кафедра гражданского и арбитражного процесса

Самарский государственный экономический университет

443090, г. Самара, ул. Советской Армии, д. 141

E-mail:2482337@mail.ru

\section{(C) 2018 Ланг Петр Петрович}

кандидат юридических наук, доцент, кафедра гражданского и арбитражного процесса

Самарский государственный экономический университет

443090, г. Самара, ул. Советской Армии, д. 141

E-mail: lvls@mail.ru

\section{(C) 2018 Чуракова Екатерина Николаевна}

кандидат юридических наук, доцент, кафедра гражданского и арбитражного процесса

Самарский государственный экономический университет

443090, г. Самара, ул. Советской Армии, д. 141

E-mail: churakovaEN@gmail.com

(c) 2018 Борисова Ирина Васильевна

магистрант, кафедра гражданского и арбитражного процесса

Самарский государственный экономический университет

443090, г. Самара, ул. Советской Армии, д. 141

E-mail: borisova.irin04ka@yandex.ru

В статье анализируются подходы к выявлению правовой природы российского нотариата. Сделан акцент на двойственности нотариата, проанализированы его некоторые аспекты.

Ключевые слова: нотариат, двойственность российского нотариата.

На сегодняшний день особо актуальными в юридической науке являются вопросы, связанные с определением составных частей, входящих в понятие нотариата, его правовой природы, места нахождения в системе отраслей права, основных функций, а также соотношения нотариата с институтами власти и гражданского общества.

Законодательство Российской Федерации не содержит определения понятия «нотариат», в связи, с чем в научной и учебной литературе существует несколько определений указанного понятия. Итак, нотариат можно понимать как:

- государственную систему органов, наделенных полномочиями властного характера, целью деятельности которых является защита прав и законных интересов общества, юридических лиц и граждан [1];

- обеспечивающий стабильный гражданский оборот, правовой институт, основной целью которого является защита прав и законных интересов юридических лиц и граждан путем совершения специальных (нотариальных) действий [2].

Также российская правовая наука содержит точку зрения относительно содержания понятия нотариата, которая указывает на комплексность исследования этого понятия, с учетом принятия во внимание предмета, содержания, целей, задач, функций нотариата, форм нотариальной деятельности и т.д. Суть описываемой точки зрения заключается в том, что с одной стороны, нотариат отождествляют с материально-правовыми институтами, а с другой - с идеей превентивного правосудия [3, 10]. Раскрывая нотариат в концепции предупредительного правосудия, стоит понимать, что его деятельность направлена не только на оказание правовой помощи физическим, юридическим лицам, на содействие в обеспечении их правовой безопасности, но и на исключение возможности возникновения споров между участками договорных отношений [4, 5].

Понимание дуалистичности нотариата ус- 
матривается также в позиции А.Е. Черникова, в которой он раскрывает нотариальную двойственность, помогающую нотариату балансировать на границе частной и публичной сфер. Нотариус как представитель гражданского общества, выступает одновременно носителем публично-правовых полномочий [5]. Неразрывность реализации нотариатом с одной стороны публичной власти, а с другой - представительства гражданского общества, «является общепризнанным фактом» [5]. Возникают некоторые сложности при определении понятия и сущности российского нотариата ввиду собирания различных начал публичного и частного.

Учитывая двойственность нотариата, выражающуюся в объединении его частного и публичного начал, многие профессоры и ученые предлагали свои варианты определения этого неоднозначного понятия, так представляется интересной точка зрения, выраженная в одной из своих работ Н.И. Комаровым, где нотариат рассматривается как орган государственной власти, осуществляющий правоохранительную деятельность, и как правовой орган гражданского общества, деятельность которого выражается в осуществлении превентивного, досудебного правосудия [6, 3]. Понимание нотариата как государственного органа требует дальнейшего изучения, на наш взгляд.

Опираясь на юридическую сущность нотариата, профессор И.Г. Черемных писал: «...нотариат осуществляет деятельность по защите законных частных и публичных интересов обращающихся лиц от имени государства, ввиду чего такая правоохранительная деятельность обладает публичным характером» [7, 35].

Исходя из ст. 7, 8 Основ законодательства Российской Федерации о нотариате (утв. ВС РФ 11.02.1993 N4462-1)(ред. от 03.08.2018)(с изм. и доп., вступ. в силу с 01.10.2018) [8] (далее - Основы о нотариате) в Российской Федерации допускается как государственный нотариат, так и частный. В юридической литературе встречается мнение о том, что частные начала нотариальной деятельности указывают на независимость нотариата ни от государства, ни от интересов лиц, обращающихся за совершением нотариальных действий $[9,5]$. Более того, некоторыми учеными были высказаны суждения, а именно: «представителями частного нотариата являются «лица свободной профессии» $[10,89]$. Указанные доводы складывались исходя из того, что нотариат хоть и осуществляется наделенными государством специальными полномочиями по защите прав и свобод граждан лицами, которые при этом выступают в качестве независимых консультантов сторон, представителями свободной профессии. На наш взгляд, указанные суждения являются ошибочными, поскольку, во-первых, частные начала нотариальной деятельности не свидетельствуют о том, что нотариус осуществляет деятельность от имени государства (как и государственный) ради получения собственной выгоды. Отмечаем, что согласно ст. 1 Основ о нотариате [8] нотариальная деятельность не является предпринимательской и не связана с целью извлечения прибыли, причем, независимо от того осуществляется нотариальная деятельность государственными нотариусами или нотариусами, занимающимися частной практикой.

Важно также отметить, что в Российской Федерации действует принцип разделения властей на законодательную, исполнительную и судебную [11]. Нотариат структурно не принадлежит ни к одной из перечисленных, но как указано в Основах о нотариате [8] нотариальная деятельность осуществляется от имени Российской Федерации. Как установлено Конституционным Судом Российской Федерации: «на основании специального государственного поручения негосударственным структурам могут быть предоставлены специальные полномочия на право совершения конкретных государственных функций [12].

Двойственность российского нотариата можно усмотреть также в том, совершение нотариальных действий может осуществляться не только нотариусами. В соответствие со ст. 37 Основ о нотариате [8] в случае, если в поселении, на межселенной территории населенном пункте нет нотариуса правом совершения нотариальных действий, предусмотренных статьей, обладают соответственно глава местной администрации поселения и (специально уполномоченное должностное лицо местного самоуправления поселения) или глава местной администрации муниципального района (специально уполномоченное должностное лицо местного самоуправления муниципального района). Право на совершение нотариальных действий, предусмотренных соответствующими статьями Основ о нотариате [8], имеют также уполномоченные должностные лица консульских учреждений РФ на территории других государств [13, 69]. 
В Гражданском кодексе Российской Федерации (часть третья) от 26.11.2001 N146-Ф (ред. от 03.08.2018) (с изм. и доп., вступ. в силу с 01.09.2018) [14] (далее - ГК РФ) предусматриваются субъекты, которые могут совершать схожие действия по заверению некоторых документов, приравнивающихся к нотариально удостоверенным. Например, в ст. 1127 ГК РФ [14] указаны следующие субъекты, которые имеют право при указанных в статье обстоятельствах удостоверять завещания: главные врачи, их заместители по медицинской части, дежурные врачи больниц, госпиталей и других медицинских организаций, начальники госпиталей, директоры или главные врачи домов для престарелых и инвалидов, капитаны судов, плавающих под флагами РФ, начальники экспедиций, командиры воинских частей, начальники мест лишения свободы.
Таким образом, нотариусы осуществляют нотариальную деятельность на территории Российской Федерации, но в исключительных, частных случаях деятельность по совершению некоторых нотариальных действий может быть перенесена на субъектов не занимающихся нотариальной деятельностью профессионально.

Подытоживая сказанное, следует отметить, что нотариат в Российской Федерации имеет свои специфические особенности, а именно: двойственная природа, которая проявляется в условиях его функционирования на стыке частно-правовых и публично-правовых начал. Таким образом, российский нотариат можно определить как один из важнейших правовых институтов, который является связующим звеном между государством и проживающим в нем обществом.

\section{Библиографический список}

1. Кулишова Р. Т. Специфика правовой природы нотариата и нотариальной деятельности в Российской Федерации // Нотариус. 2016. N7. C. 3-8.; Бегичев А. В. Сущность правозащитной деятельности нотариата в системе социальной функции государства // Нотариус. 2015. N5. С. 26-29; Нотариат в России. Схемы и комментарии: Учебное пособие / Под ред. М.К. Треушникова. Москва. 2014. С. 4.; Фадеева Г.В. Административно-правовое регулирование организации нотариальной деятельности в России: Автореф. дис. ... канд. юрид. наук. Саратов, 2012. С. 8 и др.

2. Марченко М.Н. Проблемы теории государства и права // Под ред. М.Н. Марченко. М., 2015. С. 201; Цветков А.С. Публично-правовая природа нотариальной деятельности в Российской Федерации // Современное право. 2017. N11. С. 49-53; Жуйков В.М. Нотариат как институт превентивного правосудия: общие цели, принципы и полномочия // Российская юстиция. 1998. N6. С. 33-34 и др..

3. Тарбагаева Е.Б. Организация и деятельность нотариата в РФ: уч.пособие. Москва. 2017. С. 8-15.

4. Кулишова Р. Т. Специфика правовой природы нотариата и нотариальной деятельности в Российской Федерации // Нотариус. 2016. N7. С. 3-8.

5. Кашурин И.Н. Нотариат в правовой системе Российской Федерации. Москва. 2015. С. 8; Клячин Е. Н. Конституционная гарантия каждого на получение квалифицированной юридической помощи невозможна без более полного использования потенциала нотариата // Нотариат, государственная власть и гражданское общество: современное состояние и перспективы. Москва. 2017. С. 14.

6. Комаров Н.И. Нотариат в Российской империи во второй половине XIX - начале XX века (историко-правовое исследование). Москва. 2017. С. 1-7.

7. Черемных И.Г. Теоретические основы независимого нотариата России. Москва. 2016. С. 35.

8. Основ законодательства Российской Федерации о нотариате (утв. ВС РФ 11.02.1993 N4462-1)(ред. от 03.08.2018)(с изм. и доп., вступ. в силу с 01.10.2018) // СПС «КонсультантПлюс» (дата обращения:15.11.2018).

9. Черников А.Е. Правовая природа нотариата в современной России // Управление общественными и экономическими системами. 2018. N1. С. 1-24.

10. Черемных Г.Г. Нотариальное право РФ: учебник / Г.Г. Черемных, И.Г. Черемных. Москва. 2016. С. 89.

11. Конституция Российской Федерации (принята всенародным голосованием 12.12.1993)(с учетом поправок, внесенных Законами РФ о поправках к Конституции РФ от 30.12.2008 N6-ФКЗ, от 30.12.2008 N7-ФКЗ, от 05.02.2014 N2-ФКЗ, от 21.07.2014 N11-ФКЗ) // в Собрании законодательства РФ, 04.08.2014, N31, ст. 10.

12. Постановления Конституционного Суда РФ от 19 мая 1998 года N15-П; от 19 декабря 2005 г. N12-П; Определения от 11 июля 2006 года N349-O, от 28 января 2016 года N198-O, от 12 мая 2016 года N1144-O.

13. Зайцева Т.И., Патрушева Т.В.., Перевалова И.В., Настольная книга нотариуса Организация нотариального дела: в 4 т. Москва. 2015. Т. 1: Организация нотариального дела. С. 69. 
14. Гражданский кодекс Российской Федерации (часть третья) от 26.11.2001 N146-Ф (ред. от 03.08.2018) (с изм. и доп., вступ. в силу с 01.09.2018) // СПС «КонсультантПлюс» (дата обращения: 18.11.2018).

Поступила в редакциию 07.11.2018 